\title{
Angiogenesis Markers Quantification in Breast Cancer and Their Correlation with Clinicopathological Prognostic Variables
}

\author{
Jan Rykala • Karolina Przybylowska • \\ Ireneusz Majsterek • Grazyna Pasz-Walczak • \\ Andrzej Sygut • Adam Dziki • Julia Kruk-Jeromin
}

Received: 2 September 2010 / Accepted: 9 March 2011 /Published online: 11 May 2011

(C) The Author(s) 2011. This article is published with open access at Springerlink.com

\begin{abstract}
Tumoural angiogenesis is essential for the growth and spread of breast cancer cells. Therefore the aim of this study was to assess the diagnostic performance of angiogenesis markers in tumours and there reflecting levels in serum of breast cancer patients. Angiogenin, Ang2, fibroblast growth factor basic, intercellular adhesion molecule (ICAM)-1, keratinocyte growth factor (KGF), platelet-derived growth factor-BB, and VEGF-A were measured using a FASTQuant angiogenic growth factor multiplex protein assay. We observed that breast cancer tumours exhibited high levels of PDGF-BB, bFGF and VEGF, and extremely high levels of TIMP-1 and Ang-2, whereas in serum we found significantly higher levels of Ang-2, PDGF-BB, bFGF, ICAM-1 and VEGF in patients
\end{abstract}

J. Rykala $(\bowtie) \cdot$ J. Kruk-Jeromin

Department of Plastic, Reconstructive and Aesthetic Surgery,

Barlicki Hospital, Medical University of Lodz,

Kopcinskiego 22,

90-153, Lodz, Poland

e-mail: janekrykalarykala@gmail.com

K. Przybylowska $\cdot$ I. Majsterek

Department of Chemistry and Clinical Biochemistry,

Medical University of Lodz,

Hallera 1,

90-647, Lodz, Poland

G. Pasz-Walczak

Department of Pathology, Medical University of Lodz,

Paderewskiego 4,

93-509, Lodz, Poland

A. Sygut $\cdot$ A. Dziki

Department of General and Colorectal Surgery,

Medical University of Lodz,

Hallera 1,

90-647, Lodz, Poland with breast cancer compared to the benign breast diseases patients. Moreover, some of these angiogenesis markers evaluated in tumour and serum of breast cancer patients exhibited association with standard clinical parameters, ER status as well as MVD of tumours. Angiogenesis markers play important roles in tumour growth, invasion and metastasis. Our results suggest that analysis of angiogenesis markers in tumour and serum of breast cancer patients using multiplex protein assay can improve diagnosis and prognosis in this diseases.

Keywords Breast cancer-Angiogenesis .

Cancer progression $\cdot$ Multiplex protein assay

\section{Background}

The formation of new microvessels from preexisting vessels is necessary for tumor growth, and subsequent tumour metastasis that involves the interaction of neoplastic cells with that neovasculature. Angiogenesis depends on endothelial cell migration, proliferation and differentiation. The process of new vessel development, partially reflects the characteristics of the genetically unmodified stromal tissue of the host, and is involved in three key pathophysiologjcal events resulting in the disease progression, cancer tumour cell proliferation, invasion and hematogenous spread [1-3]. A number of studies have reported that hematogenous spread of tumour cells is quantitatively related to intratumoural microvessel density (MVD). These data shows that the increased MVD is associated with a higher incidences of metastasis and a poor prognosis in various malignancies, including breast cancer [4-7]. Usually, angiogenesis is controlled by interactions among 
growth factors, vascular cells and the extracellular matrix. This interaction is out of balance in cases of malignancy because of tumor-associated angiogenic factors that can be produced directly by cancer cells or indirectly by inflammatory cells that infiltrate tumor [1-3]. According to existing data, elevated levels of angiogenesis markers in both tumour and serum, have been observed in patients with different types of cancer [8-10]. r, The correlation between levels of angiogenesis regulated factors, clinical pathology and prognosis is very significant, especially in breast cancer [11-13].

In order to elucidate the potential clinical relevance of the angiogenic activity, we estimated the levels of angiogenic molecules: bFGF, PDGF, KGF, VEGF, Ang, (Ang-2), ICAM-1 and TIMP-1 as well in tumour as in the corresponding serum samples of patients with invasive breast cancer and benign breast disease. Association between these markers and clinical parameters of tumour may have potential value in diagnosis and prognosis of breast cancer. It is very important since available prognostic parameters (lymph node status, tumor size, grade of malignancy, ER, PR and HER2 status) are relatively inadequate to precisely define the prognosis of individual patient. Identification of molecular profile of individual tumors is useful to define subgroups of patients fitting into different treatment schemes, and it's considered a most promising approach in cancer research to improve clinical outcome. Angiogenesis markers play important role in tumour growth, invasion and metastasis, and therefore they seems to be excellent set of candidates for prognostic factors.

\section{Patients}

Primary breast tumour tissues $(n=127)$ were obtained from Caucasian patients during primary curative resection, at the Department of Surgical Oncology N. Copernicus Hospital in Lodz, Poland between 2005 and 2009. The subjects were 36 to 84 years old with median age of 62.6 years. All patients had histologically-confirmed primary breast cancer (ductal breast carcinoma $(n=105)$ and lobular carcinoma $(n=22))$ and benign breast disease (fibroadenoma $(n=38)$ and ductal hyperplasia $(n=16))$. Additionally, blood samples were collected preoperatively from breast cancer patients $(n=76)$ and women with benign tumor $(n=38)$. A database comprising detailed clinical data regarding diagnosis and histopathological variables of invasive breast cancer patients was created (Table 1.). None of the breast cancer patients received neoadjuvant therapy. Written informed consent had been obtained from all participating subjects and the study had been approved by the local Ethics Committee of Medical University of Lodz.
Table 1 The clinical characteristics of patients with invasive breast cancer

\begin{tabular}{ll}
\hline Clinical characteristics & Patients $(n=127)$ number/frequencies \\
\hline Histological grade & \\
Well Dif. & $8 / 0.06$ \\
Mod. Dif & $55 / 0.43$ \\
Poorly Dif. & $64 / 0.51$ \\
Nodal Status & \\
N (-) & $71 / 0.56$ \\
N (+) & $56 / 0.44$ \\
Distance metastasis & \\
Positive & $21 / 0.16$ \\
Negative & $106 / 0.84$ \\
Tumoural size & \\
T1 & $44 / 0.35$ \\
T2 & $65 / 0.51$ \\
T3/T4 & $18 / 0.14$ \\
Estrogen receptors & \\
Positive & $85 / 0.67$ \\
Negative & $42 / 0.33$ \\
Progesterone receptors & \\
Positive & $59 / 0.46$ \\
Negative & $68 / 0.54$ \\
MVD ( $n=54)$ & \\
High (score $\geq .26)$ & $22 / 0.41$ \\
Low (score $<.26)$ & $32 / 0.59$ \\
\hline
\end{tabular}

\section{Breast Tissues Sampling}

Breast cancer specimens of at least $100 \mathrm{mg}$ were obtained from the tumor core at the time of surgery from each patient. The specimens were verified by the study pathologist to be invasive mammary carcinomas or benign breast disease. Cell density was assessed in proteinase $\mathrm{K}$ digests by measuring DNA and normalizing it to tissue total protein. As a normalization measure for the DNA assessments, sample total protein was quantitated. The total protein and DNA concentration was calculated by the Qubit $^{\text {TM }}$ Quantitation Fluorometer (Invitrogen, California, USA). Tissue DNA content is a standard indirect measure of tissue cellularity, therefore, carcinomas specimens and benign breast disease specimens DNA levels were converted to cell numbers by dividing by 6.9 pg DNA per cell or by $6.6 \mathrm{pg}$ DNA per cell, respectively. Fragments of benign lesion tumour (25-35\% cellularity) and representative specimens with more than $70 \%$ tumour cells from breast cancer were then immediately shock frozen and cryopreserved $\left(-70^{\circ} \mathrm{C}\right)$ for subsequent assay preparations. For FastQuant analysis, tissues of all specimens were homogenized in the extraction buffer $(0.005 \mathrm{M}$ Tris- $\mathrm{HCl}$, 
$\mathrm{pH}$ 8) with addition of a cocktail of protease inhibitors (La Roche, France) in the presence of $0.5 \%$ Triton X-100. Homogenates were centrifugated for $10 \mathrm{~min}$ at $10,000 \mathrm{rpm}$. The protein concentration of supernatants was calculated by the Qubit ${ }^{\mathrm{TM}}$ Quantitation Fluorometer.

\section{Blood Sampling}

Patients sera was obtained by peripheral venous blood collection which were carried out on the day of surgery. Blood samples had been collected without anticoagulant into serum separator vacutainers and allowed to coagulate for 20 to $30 \mathrm{~min}$ at room temperature. Sera were separated by centrifugation $(2,000 \mathrm{rpm}, 10 \mathrm{~min})$, and all specimens were aliquot immediately, frozen, and stored in a $-70^{\circ} \mathrm{C}$ freezer.

\section{Evaluation of ER and PR}

Levels of ER and PR within the tumors of the cases had been determined by immunohistochemistry as part of the routine clinical practice. Using the immunohistochemical assay, tumors were classified as positive if more than $10 \%$ of the cells showed nuclear staining for the receptor. We obtained the information on ER and PR within the tumors of the cases from the pathology reports.

\section{FASTQuant ${ }^{\circledR}$ Microspot Assays for Angiogenesis Factor Quantification}

A FASTQuant human angiogenesis array for angiogenin, Ang2, platelet-derived growth factor (PDGF)-BB, VEGFA, fibroblast growth factor basic (FGF-b), keratinocyte growth factor (KGF), and intercellular adhesion molecule (ICAM)-1 was run according to the manufacturer's instructions (Whatman Schleicher and Schuell, Dassel, Germany). Built on FAST Slide technology, which is based upon high protein binding capacity surface chemistry, FAST Quant ${ }^{\circledR}$ combines the power of array technology with the quantitative nature and high-throughput capabilities of traditional ELISA. The FAST Slide 3-D nitrocellulose surface is the industry standard for protein arrays due to its high capacity and positive influence on protein binding and stability. Each kit contains four glass slides arranged with 16 nitrocellulose pads on which reference markers and capture antibody for analytes in that array are dotted in triplicate using nanodot technology. The kit also includes biotinylated detection antibodies and recombinant antigen standards for generating a standard curve. The quantitative analyses of angiogenic molecules were simultaneously performed under the same conditions using a 7-point mass standard curve. Briefly, slides were blocked in $70 \mu \mathrm{l}$ blocking buffer for $30 \mathrm{~min}$ with shaking at room temperature; blocking buffer was removed and $70 \mu \mathrm{l}$ samples of breast tissues and serum or standards were added to the appropriate well and incubated overnight. The slides were washed three times, then $70 \mu$ l biotinylated detection antibody $(\mathrm{Ab})$ was added and incubated for $1 \mathrm{~h}$. After another three washes, $70 \mu 1$ streptavidin-Cy5 solution was added, the slides were incubated for $45 \mathrm{~min}$ in the dark, washed three times, and allowed to dry. The slides were imaged using a GenePix scanner (Axon, Molecular Devices, Workingham, Berks, UK). In order to evaluate the microarray images we customized the spot intensities comparison routines available within "The R Project For Statistical Computing" version 2.5.1 (Fig. 1). A log transformation of the signal from the samples permitted comparison to the standard curve to approximate the concentrations of the angiogenic molecules. The dynamic range for angiogenin and VEGF was 2.4-2,500 pg/ml and for all other analytes, was $12.2-12,500 \mathrm{pg} / \mathrm{ml}$.

\section{Assessment of MVD}

"Blood Sampling" micro millimeters thick of formalinefixed, paraffin embedded tissue were placed on SuperFrost Plus slides (Menzel-Glaser, Braunschweig, Germany). These were deparaffinized in xylenes and rehydrated through graded alcohols. Then, the sections were heated in DakoCytomation Target Retrival Solution (DAKO, Glostrup, Denmark), $\mathrm{pH} 9,0$, for $20 \mathrm{~min}$ in water bath to epitope retrieval. After the slides were cooled for $20 \mathrm{~min}$ and incubated for $30 \mathrm{~min}$ at room temperature with the primary monoclonal antibody anti-CD34 (clone QBEnd-10, 1:50 dilution, DAKO, Glostrup, Denmark), and processed with EnVision+(DAKO, Glostrup, Denmark) system. Sections were counterstained with haematoxylin, dehydrated with ethanol, cleared in xylene and sticked with Canada balsam. Evaluation of number of vessels was done according to Weidener's method and its further modifications $[14,15]$. Slides were estimated under 100x magnification to take out areas of the biggest condensation of vessels (hot spots). Next number of vessels was counted under 400x magnification (HPV, Olympus, BH). As positive result of imunohistochemistry any single positively coloured cell or group of cells was evaluated, even in cases without inside measurement of a vessel. Vessels laing beside each other were counted independly if only one stroma cell was found between them. Next mean number of vessels of $10 \mathrm{HPV}$ was estimated. 
Fig. 1 The pad of FASTQuant human angiogenesis array slides showing a typical array result for barest cancer tumor sample. Inserts show the array map for FAST Quant, D represents spots containing donkey anti-goat Ig to act as landing light controls

\begin{tabular}{|c|c|c|c|c|c|}
\hline D & D & D & PBS & PBS & PBS \\
\hline Ang & Ang & Ang & KGF & KGF & KGF \\
\hline Ang-2 & Ang-2 & Ang-2 & $\begin{array}{c}\text { PDGF } \\
\text {-BB }\end{array}$ & $\begin{array}{c}\text { PDGF } \\
\text {-BB }\end{array}$ & $\begin{array}{c}\text { PDGF } \\
\text {-BB }\end{array}$ \\
\hline $\begin{array}{c}\text { FGF- } \\
\text { b }\end{array}$ & $\begin{array}{c}\text { FGF- } \\
\text { b }\end{array}$ & $\begin{array}{c}\text { FGF- } \\
\text { b }\end{array}$ & $\begin{array}{c}\text { TIMP- } \\
1\end{array}$ & $\begin{array}{c}\text { TIMP- } \\
1\end{array}$ & $\begin{array}{c}\text { TIMP- } \\
1\end{array}$ \\
\hline $\begin{array}{c}\text { ICAM- } \\
1\end{array}$ & $\begin{array}{c}\text { ICAM- } \\
1\end{array}$ & $\begin{array}{c}\text { ICAM- } \\
1\end{array}$ & VEGF & VEGF & VEGF \\
\hline D & D & D & D & D & D \\
\hline
\end{tabular}

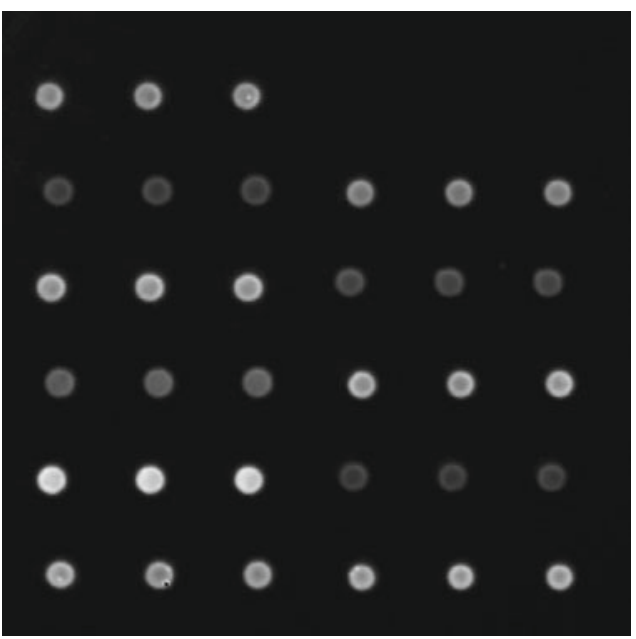

\section{Statistical Methods}

Statistical programs for SigmaStat version 3.5 was used for data base management and analysis. Quantitative data were summarized in the form of means, standard deviation, median and quartiles. t- test and Mann-Whitney test was used to compare the level of serum and tumour angiogenesis marker levels in breast cancer patients and benign breast disease patients. The median levels of expression of analyzed angiogenesis markers were compared using Kruskal-Wallis test according to clinical data (grading, ER, PR, nodal status, tumoural size, MVD) or analysis of variance if possible. For correlation analysis Pearson's correlation coefficient $\mathrm{r}$ and the $p$-values were determined. For all statistical analysis, $P<0.05$ was considered statistically significant.

\section{Results}

\section{Angiogenesis Markers Tumors Levels}

A total of 127 samples of primary invasive breast carcinomas and 54 benign breast disease were analyzed for 8 angiogenesis markers at the protein level. We observed that breast cancer tumours exhibited high levels of PDGF-BB, and VEGF, and extremely high levels of TIMP-1 and Ang-2, which were over-expressed and barred performance of test for normality. In contras the Ang, bFGF, KGF and ICAM-1 were detected in either benign breast disease or tumour sample on similarly levels. (Table 2). Next we evaluated, if angiogenesis markers levels in tumour could be linked to clinical parameters such as histological grade, tumour size, lymph node status (Table 3). Positive lymph node status was linked to elevated of VEGF and ICAM-1 expression.
Distant metastases was associated with high VEGF level. Additionally ICAM-1 was more abundant in breast cancer tumour with advanced $\mathrm{T}$ stage and we found that VEGF was significantly over-expressed in ER-positive tumours compared with ER-negative. We did not observe similar relationship for PR status. We did not observe any correlation between histological type and angiogenesis markers levels.

\section{Angiogenesis Markers Serum Levels}

We obtained and analyzed serum samples from 76 breast cancer patients and 38 benign breast disease patients. We found significantly higher serum levels of Ang-2, PDGFBB, bFGF, ICAM-1 and VEGF in patients with breast cancer compared to the benign breast diseases patients. There were no significant differences in serum Ang and TIMP-1 levels between the both groups of patients (Table 2). The concentration of KGF in benign breast disease patients and cancer patients be was undetectable in most individuals. Regarding bFGF only 23 breast cancer patients had measurable serum level of bFGF. For this reason we excluded KGF and bFGF from further analysis. We performed the same type of analysis to identify if there was any correlation between serum angiogenesis markers levels and clinical parameters (Table 4). The analysis revealed that the largest differences were obtained for PDGF-BB levels which were very high in serum breast cancer patient with advanced $\mathrm{T}$ stage tumors. Additionally we demonstrated that patients with lymph node metastases had higher TIMP-1, ICAM-1 and VEGF serum level. We observed a trend to higher level of TIMP-1 and VEGF serum level in patients with distance metastases but it wasn't statistic significant. There were no relationship between remaining serum angiogenesis marker and clinical-pathologic parameters of breast cancer. 
Table 2 Average level of angiogenesis markers in tumour and serum of breast cancer patients and benign lesion breast patients. (mean \pm SD)

\begin{tabular}{|c|c|c|c|c|c|c|}
\hline \multirow[t]{2}{*}{ Markers } & \multicolumn{3}{|l|}{ Tumour pg/mg } & \multicolumn{3}{|l|}{ Serum $\mathrm{pg} / \mathrm{ml}$ or $\mathrm{ng} / \mathrm{ml}$} \\
\hline & Breast cancer & Benign lesion & $P$ value & Breast cancer & Benign lesion & $P$ value \\
\hline Ang & $6,673(795)$ & $5,715(952)$ & $p=0.88$ & $2,341(764) \mathrm{pg} / \mathrm{ml}$ & $1,986(421) \mathrm{pg} / \mathrm{ml}$ & $p=0.67$ \\
\hline Ang-2 & Overexpress & $1,645(1,185)$ & - & $7,111(1,761) \mathrm{pg} / \mathrm{ml}$ & $5,409(2,167) \mathrm{pg} / \mathrm{ml}$ & $p<0.01$ \\
\hline KGF & $117(321)$ & $98(421)$ & $p=0.76$ & $421(122) \mathrm{pg} / \mathrm{ml}$ & Undetectable & - \\
\hline PDGF-BB & $2,476(7,954)$ & $894(1,789)$ & $p=0.02$ & $7,623(5,198) \mathrm{pg} / \mathrm{ml}$ & $5,428(1,782) \mathrm{pg} / \mathrm{ml}$ & $p=0.02$ \\
\hline bFGF & $1,759(485)$ & $1,434(332)$ & $p=0.28$ & 167 (112) pg/ml & $22(98) \mathrm{pg} / \mathrm{ml}$ & $p<0.001$ \\
\hline TIMP-1 & Overexpress & $24,687(32,885)$ & - & $31(38) \mathrm{ng} / \mathrm{ml}$ & 41 (39)ng/ml & $p=0.34$ \\
\hline ICAM-1 & $18,760(7,802)$ & $12,874(6,743)$ & $p=0.06$ & $1,213(903) \mathrm{ng} / \mathrm{ml}$ & 327 (78)ng/ml & $p=0.008$ \\
\hline VEGF & $1,786(2,980)$ & $936(1,873)$ & $p=0.04$ & $132(102) \mathrm{ng} / \mathrm{ml}$ & $53(231) \mathrm{ng} / \mathrm{ml}$ & $p=0.009$ \\
\hline
\end{tabular}

Relationship of Angiogenesis Markers to MVD

MVD was measured in 54 samples and ranged from 0.0 to 110.0 , with a mean standard deviation of $25.8 \pm 15.8$.
Tumors were classified into two groups: those with an MVD score $\leq 26$ (low MVD; $n=32$ patients) and $\geq .26$ (high MVD; $n=22$ patients). The breast cancer tumours with rich network of blood vessels presented significantly higher

Table 3 Tumour angiogenesis markers in relation to clinical, pathological and biological characteristics in breast cancer patients. Median (quartiles)

\begin{tabular}{|c|c|c|c|c|c|c|}
\hline Clinical variables & Ang pg/mg & $\mathrm{KGF} \mathrm{pg} / \mathrm{mg}$ & PDGF-BB pg/mg & bFGF pg/mg & ICAM-1 ng/mg & VEGF $\mathrm{pg} / \mathrm{mg}$ \\
\hline \multicolumn{7}{|c|}{ Histological grade } \\
\hline Well Dif. & $5,432(2,171,8,481)$ & $51(29,287)$ & $8,612(4,572,10,894)$ & $1,402(160 ; 3,831)$ & $11,737(7,924,1,821)$ & $3,271(233 ; 5,783)$ \\
\hline Mod. Dif. & $4,189(3,341 ; 7,761)$ & $44(11 ; 512)$ & $9,781(6,608 ; 12,871)$ & $674(203 ; 1,780)$ & $14,139(10,989 ; 18,665)$ & $1,043(613 ; 5,310)$ \\
\hline Poorly Dif. & $5,633(3,320 ; 7,195)$ & $88(14 ; 206)$ & $5,317(2,678 ; 7,629)$ & $431(198 ; 3,103)$ & $13,335(11,467 ; 17,422)$ & $2,115(764 ; 7,193)$ \\
\hline \multicolumn{7}{|l|}{ Nodal Status } \\
\hline $\mathrm{N}(-)$ & $3,819(2,624 ; 6,199)$ & $53(11 ; 176)$ & $8,721(2,718 ; 10,076)$ & $931(298 ; 1,765)$ & $11,097(8,419 ; 15,672)$ & $812(139 ; 3,203)$ \\
\hline \multirow[t]{2}{*}{$\mathrm{N}(+)$} & $4,111(3,719 ; 9,143)$ & $62(25 ; 221)$ & $5,929(1,572 ; 10,842)$ & $754(195 ; 3,915)$ & $19,920(13,151 ; 21,981)$ & $4,033(1,251 ; 9,883)$ \\
\hline & & & & & $p=0.004$ & $p=0.003$ \\
\hline \multicolumn{7}{|c|}{ Distance metastases } \\
\hline $\mathrm{M}(-)$ & $5,633(2,088,8,301)$ & $53(29,512)$ & $6,723(1,281,10,894)$ & $645(276 ; 3,354)$ & $12,151(10,989 ; 19,001)$ & $1,043(764 ; 6,062)$ \\
\hline \multirow[t]{2}{*}{$\mathrm{M}(+)$} & $4,187(2,762,9,143)$ & $75(25,345)$ & $8,612(2,678,11,234)$ & $876(198,4,234)$ & $17,623(12,342 ; 19,811)$ & $4,519(1,251 ; 8,341)$ \\
\hline & & & & & & $p=0.02$ \\
\hline \multicolumn{7}{|l|}{ Tumoural size } \\
\hline $\mathrm{T} 1$ & $4,187(3,668 ; 8,149)$ & $112(37 ; 222)$ & $5,619(1,036 ; 9,519)$ & $1,362(160 ; 2,339)$ & $11,270(9,880 ; 13,030)$ & $3,732(1,233 ; 5,761)$ \\
\hline $\mathrm{T} 2$ & $5,298(2,088 ; 7,194)$ & $75(21 ; 345)$ & $9,522(648 ; 10,746)$ & $914(40 ; 3,354)$ & $14,613(9,975 ; 16,341)$ & $2,387(587 ; 6,062)$ \\
\hline \multirow[t]{2}{*}{$\mathrm{T} 3 / \mathrm{T} 4$} & $6,199(2,088 ; 8,172)$ & $86(31 ; 288)$ & $9,522(648 ; 10,746)$ & $9,522(648 ; 10,746)$ & $17,812(11,725 ; 19,001)$ & $2,101(542 ; 7,452)$ \\
\hline & & & & & $p=0.001$ & \\
\hline \multicolumn{7}{|l|}{ ER } \\
\hline Positive & $5,984(3,327 ; 8,193)$ & $53(41 ; 305)$ & $4,391(1,281 ; 8,719)$ & $571(123 ; 4,165)$ & $16,017(10,219 ; 19,811)$ & $4,519(778 ; 7,538)$ \\
\hline \multirow[t]{2}{*}{ Negative } & $4,812(2,081 ; 8,481)$ & $38(11 ; 222)$ & $8,612(2,804 ; 11,281)$ & $402(73 ; 2,642)$ & $12,129(10,635 ; 13,953)$ & $1,218(135 ; 3,105)$ \\
\hline & & & & & & $p=0.003$ \\
\hline \multicolumn{7}{|l|}{ PgR } \\
\hline Positive & $7,325(6,118 ; 9,921)$ & $61(22,337)$ & $5,522(1,821 ; 8,933)$ & $691(47 ; 2,331)$ & $18,542(9,218 ; 16,841)$ & $3,203(233 ; 3,609)$ \\
\hline Negative & $5,409(4,582 ; 8,816)$ & $32(21 ; 236)$ & $7,801(4,193 ; 9,832)$ & $512(163 ; 1,692)$ & $17,627(11,827 ; 14,116)$ & $1,716(657 ; 5,081)$ \\
\hline \multicolumn{7}{|l|}{$\operatorname{MVD}(n=54)$} \\
\hline High $(\geq .26)$ & $7,145(4,768 ; 8,100)$ & $45(8 ; 373)$ & $9,519(8,366 ; 14,076)$ & $266(23 ; 745)$ & $15,030(12,259 ; 18,516)$ & $1,946(564 ; 4,736)$ \\
\hline \multirow[t]{2}{*}{ Low $(<.26)$} & $4,161(3,199 ; 7,169)$ & $50(9 ; 138)$ & $3,238(1,365 ; 5,622)$ & $1,475(13 ; 3,909)$ & $11,448(8,917 ; 15,916)$ & $957(167 ; 2,987)$ \\
\hline & & & $p=0.004$ & $p=0.006$ & $p=0.01$ & $p=0.018$ \\
\hline
\end{tabular}


Table 4 Serum angiogenesis markers in relation to clinical, pathological and biological characteristics in breast cancer patients. Median (quartiles)

\begin{tabular}{|c|c|c|c|c|c|c|}
\hline Clinical variables & Ang $\mathrm{pg} / \mathrm{mg}$ & Ang-2 pg/mg & PDGF-BB pg/mg & TIMP-1 ng/mg & ICAM-1 ng/mg & VEGF pg/mg \\
\hline \multicolumn{7}{|l|}{ Histological grade } \\
\hline Well Dif. & $3,516(-;-)$ & $3,004(-;-)$ & $5,897(-;-)$ & $32.8(-;-)$ & $916(-;-)$ & $118(-;-)$ \\
\hline Mod. Dif. & $1,651(343 ; 3,219)$ & $4,731(2,097 ; 8,654)$ & $3,876(2,544 ; 8,186)$ & $41.6(10.4 ; 51.2)$ & $911(578 ; 1,423)$ & $151(33 ; 312)$ \\
\hline Poorly Dif. & $2,291(331 ; 5,617)$ & $3,457(1,140 ; 21,094)$ & $3,643(3,159 ; 13,437)$ & $26.1(14.5 ; 41.7)$ & $777(701 ; 898)$ & $137(21 ; 202)$ \\
\hline \multicolumn{7}{|l|}{ Nodal Status } \\
\hline $\mathrm{N}(-)$ & $1,761(351 ; 5,498)$ & $5,394(1,439 ; 7,504)$ & $5,739(3,188 ; 8,639)$ & $18.3(11.7 ; 31.7)$ & $765(513 ; 1,101)$ & $51(11 ; 143)$ \\
\hline \multirow[t]{2}{*}{$\mathrm{N}(+)$} & $1,999(328 ; 4,316)$ & $3,241(2,323 ; 9,189)$ & $4,139(2,317 ; 7,386)$ & $51.0(38.7 ; 52.1)$ & $1,333(854 ; 1,732)$ & $182(56 ; 411)$ \\
\hline & & & & $p=0.02$ & $p=0.004$ & $p=0.0007$ \\
\hline \multicolumn{7}{|c|}{ Distance metastases } \\
\hline $\mathrm{M}(-)$ & $1,999(421 ; 5,498)$ & $5,761(1,439 ; 9,891)$ & $6,442(2,131,13,437)$ & $26.1(14.5 ; 54.8)$ & $765(534 ; 1,871)$ & $154(21 ; 298)$ \\
\hline $\mathrm{M}(+)$ & $1,651(341,6,521)$ & $3,457(1,786 ; 10,938)$ & $8,984(3,177 ; 17,871)$ & $48.3(21.7 ; 62.1)$ & $916(429 ; 1,415)$ & $198(31 ; 390)$ \\
\hline \multicolumn{7}{|l|}{ Tumoural size } \\
\hline $\mathrm{T} 1$ & $1,301(411 ; 2,651)$ & $4,319(1,324 ; 11,227)$ & $3,528(2,131 ; 4,467)$ & $35.1(15.2 ; 62.1)$ & $823(675 ; 963)$ & $161(23 ; 187)$ \\
\hline $\mathrm{T} 2$ & $1,765(341 ; 4,159)$ & $6,412(2,317 ; 8,415)$ & $6,182(3,177 ; 11,981)$ & $21.5(14.8 ; 48.3)$ & $779(534 ; 1,087)$ & $103(31 ; 298)$ \\
\hline \multirow[t]{2}{*}{$\mathrm{T} 3 / \mathrm{T} 4$} & $1,287(421 ; 3,329)$ & $5,761(1,786 ; 8,761)$ & $8,984(4,107 ; 17,871)$ & $32.5(21.7 ; 54.8)$ & $654(214 ; 1,871)$ & $154(11 ; 312)$ \\
\hline & & & $p=0.003$ & & & \\
\hline \multicolumn{7}{|l|}{ ER } \\
\hline Positive & $1,256(435 ; 3,813)$ & $6,683(1,928 ; 8,913)$ & $3,651(2,544 ; 8,193)$ & $27.3(11.4 ; 52.3)$ & $812(429 ; 1,126)$ & $123(41 ; 390)$ \\
\hline Negative & $1,718(243 ; 5,068)$ & $4,332(21,977 ; 10,938)$ & $5,109(3,620 ; 7,719)$ & $21.5(8.9 ; 41.4)$ & $701(568 ; 913)$ & $169(31 ; 272)$ \\
\hline \multicolumn{7}{|l|}{ PgR } \\
\hline Positive & $1,912(452 ; 4,935)$ & $5,769(2,332 ; 9,891)$ & $4,326(2,624 ; 7,749)$ & $25.4(11.5 ; 62.1)$ & $689(548 ; 1,415)$ & $198(29 ; 367)$ \\
\hline Negative & $1,105(322 ; 5,284)$ & $4,283(1,327 ; 12,021)$ & $6,442(3,957 ; 8,334)$ & $38.3(14.4 ; 52.3)$ & $869(622 ; 8,712)$ & $154(36 ; 433)$ \\
\hline \multicolumn{7}{|l|}{$\operatorname{MVD}(n=54)$} \\
\hline $\operatorname{High}(\geq .26)$ & $1,853(491 ; 4,163)$ & $6,782(3,219 ; 12,059)$ & $6,932(3,645 ; 21,945)$ & $21.5(10.8 ; 47.5)$ & $791(577 ; 961)$ & $193(45 ; 512)$ \\
\hline \multirow[t]{2}{*}{ Low $(<.26)$} & $1,498(315 ; 5,441)$ & $8,716(1,971 ; 9,815)$ & $4,197(2,397 ; 7,511)$ & $35.0(18.7 ; 45.5)$ & $740(483 ; 919)$ & $144(21 ; 602)$ \\
\hline & & & $p=0.002$ & & & \\
\hline
\end{tabular}

levels of PDGF-BB, ICAM-1 and VEGF, in contrast bFGF level inversely related with MVD. In serum, similar correlation was observed only for PDGF-BB.

\section{Correlation Analyses}

Pearson's correlation coefficient and $p$-values (significance) were calculated between angiogenesis markers tumour and serum levels in patients with breast cancer and benign breast diseases (Table 5). Tumours levels of ICAM-1 and VEGF displayed a highly significant correlation with serum levels in breast cancer patients group. No statistically significant correlation between serum Ang, KGF, PDGF$\mathrm{BB}$ and bFGF levels as determined by the tumour levels was found. We also haven't found any significant correlation between tumour and serum levels of angiogenesis markers in benign breast diseases patients group.

\section{Discussion}

Angiogenesis is critical for tumour growth and progression and is mediated by a multitude of angiogenic factors and inhibitors. These factor promote tumour development not only by activation of intratumural neovascularisation but also by direct interaction with cancer cells [1-3]. Our results from breast cancer specimens confirm that hypothesis. We found significantly higher levels of angiogenic growth factors, PDGF-BB, VEGF as well as angiogenic mediators TIMP-1 and Ang-2 in breast cancer tumour compared to benign breast disease tumour. These results suggest a close association of tissue angiogenic factors and breast cancer tumour progression.

A number of studies shown that VEGF secretion by tumor cells is a prerequisite of tumour development, and that VEGF was required for the initial stages of breast tumour genesis [16]. Recent data have shown that increased tumour level of VEGF might be associated with early relapse and reduced survival in primary breast cancer [17]. Moreover, in breast cancer tumour VEGF level is known to be correlated with both high MVD and positive nodal status. Thus, VEGF is suggested to play a key role in the angiogenic response essential for breast cancer growth, but it also seems to be involved in metastases. Furthermore, our data demonstrated a significantly higher VEGF levels in ER positive tumour, that's also confirmed by previous 
Table 5 Correlation analysis between angiogenesis markers serum and tumour levels in patients with breast cancer and benign breast diseases

\begin{tabular}{|c|c|c|c|c|}
\hline \multirow[t]{3}{*}{ Markers } & \multicolumn{2}{|l|}{ Breast cancer patients } & \multicolumn{2}{|l|}{ Benign lesion breast patients } \\
\hline & \multicolumn{2}{|l|}{ Tumour/serum } & \multicolumn{2}{|l|}{ Tumour/serum } \\
\hline & Pearson's correlation coefficient $r$ & $P$ value & Pearson's correlation coefficient $r$ & $P$ value \\
\hline Ang & 0.23758 & $p=0.76$ & 0.26332 & $p=0.19$ \\
\hline Ang-2 & Tumoural overexpression & - & 0.43572 & $p=0.06$ \\
\hline KGF & 0.31184 & $p=0.07$ & Serum undetectable & - \\
\hline PDGF-BB & 0.42718 & $p=0.08$ & 0.33523 & $p=0.07$ \\
\hline bFGF & 0.36373 & $p=0.34$ & 0.20972 & $p=0.79$ \\
\hline TIMP-1 & Tumoural overexpression & - & 0.30822 & $p=0.53$ \\
\hline ICAM-1 & 0.59773 & $p<0.002$ & 0.62917 & $p<0.01$ \\
\hline VEGF & 0.69719 & $p<0.001$ & 0.20102 & $p=0.43$ \\
\hline
\end{tabular}

results indicating the $17 \mathrm{~b}$-estradiol (E2) factor involved in direct mechanism of VEGF gene transcription regulation in ER dependent manner [18]. Therefore, different studies demonstrated negative correlation between VEGF expression and ER status resulting from BRCA1 activation [19]. Although we observed only weak correlation between VGEF serum and tumour levels of breast cancer patients, we found higher VEGF serum levels for positive nodal status subjects. Only a few data have confirmed VEGF serum level as an independent prognostic factor of breast cancer so far. Present study supported recent findings that VEGF-rich tumours are associated with breast cancer progression and distance metastases formation.

The divergence of VEGF as prognostic factor may be caused by synergistic influence of other angiogenic. In our work increased levels of PDGF-BB, bFGF in breast cancer tissue were associated with change in microvessels tumour count. What's interesting, PDGF-BB was higher in high MVD tumor whereas bFGF inversely related to MVD. It is surprising, since in number of tumours including breast cancer expression both of these angiogenic factor is induced by HIF-1 under hypoxia conditions [20]. PDGF is a potent mitogen and chemoattractant for mesenchymal cells and fibroblasts which is involved in vessel maturation through the recruitment of smooth muscle cell and pericytes to growing vessels during angiogenesis [21]. In breast cancer tumour PDGF-BB enhances angiogenesis and growth by stimulating of VEGF expression in tumor endothelium that increases EC mitogenesis [22]. These data confirmed our findings because we also observed association between higher levels of both VEGF and PDGF-BB and high MVD tumour. Additionally, increased levels of serum PDGF-BB associated with tumour size indicating that this factor may be closely related to tumor growth.
bFGF, next to its paracrine effect, is involved in an autocrine loop stimulating endothelial cell proliferation [23]. Regarding bFGF, only 11 breast cancer patients had measurable serum level and bFGF tumour level was inversely related to MVD. Previously, similar dependence have been demonstrated in prostate cancer [24]. However, in several studies no relationship between bFGF and MVD has been found. The correlation of serum and tumour bFGF levels with other clinical parameters are showed no direct interaction between bFGF expression and angiogenesis in breast cancer [20, 25, 26].

TIMP-1 is an inhibitor of the MMPs, which may have a key role in cancer cell dissemination and endothelial cell migration in angiogenesis [27]. The unexpected association between high tumor tissue levels of TIMP-1 and a poor prognosis in breast cancer seems to be a result of cancerpromoting functions. Recently, it has been demonstrated that TIMP-1 might be one of the factors involved in such a stimulation of proliferation and inhibition of apoptosis [28, 29]. Furthermore TIMP-1 which is secreted by fibroblast may inhibit the production of tumstatin, an antiangiogenic fragment of collagen IV that is produced by MMP-9 cleavage and thus increased vessel assembly [30]. In our work, we observed over-expression of TIMP-1 specific for tumor tissue with no association with other clinical parameters was estimated. In serum we found significantly higher TIMP-1 level in breast cancer specimens compared with benign stage of breast disease. Moreover, we observed high association between TIMP-1 expression and tumor's size as well as high level of MVD. We suggest that these observation may confirm the mitogenic and proangiogenic function of TIMP-1 in breast cancer.

ICAM1 has been proposed as a likely candidate for prognostic factor to breast cancer. Soluble levels of ICAM1 in the sera of patients with stage IV breast cancer were higher than that of healthy controls [31] and patients with 
lower grade tumors [32]. ICAM-1 is hypothesized to be facilitates the attachment of carcinoma cells to the lymphatic endothelial cells and therefore, promote the micrometastatic in regional lymph node. ICAM-1 expression was strongly observed around and within the metastatic region of sentinel lymph node isolated from breast cancer patients [33]. In this study, we shown a significantly higher intratumoural ICAM-1 levels in samples from patients with lymph node metastases, more advanced $\mathrm{T}$ stage and high MVD tumours. These findings validate hypothesis that ICAM-1 may promote the development of metastases, therefore ICAM-1 tumour as well as serum level may be used as poor prognostic factor in breast cancer patients.

Many investigations have demonstrated that Ang-2 overexpression is significantly associated with tumourgenesis and cancer progression [34-36]. Our results confirm these findings, we observed Ang-2 over-expression in tumour of breast cancer. Unfortunately we did not show any significant differences in Ang-2 serum levels between breast cancer patients and benign stage of breast diseases patients. This suggest that not only cancer tumours is a serum Ang-2 source.

Additionally, our results demonstrated that some of the potent angiogenetic factors of KGF and Ang are present in both cancer and benign disease of breast so their levels cannot be associated with any clinical parameters. It seems that KGF and Ang are involved in breast cancer development but not in progression of this disease.

\section{Conclusions}

Overall, obtained results confirmed that angiogenetic factors play important role in tumour growth, invasion and metastasis so they can be used as prognostic markers of breast cancer. In recent years, antiangiogenic therapy has demonstrated significant activity in patients with metastatic breast cancer. Some patients with previously untreated metastatic breast cancer, can now recive anti-VEGF monoclonal antibodies (bevacizumab) combined with standard chemotherapy doubled progression-free survival [37]. Unfortunately breast cancer treatment is still far from perfect. The evaluation of angiogenic markers set in tumour and serum may therefore play important role in selecting breast cancer patients for combination therapy consisting individual chosen antyangiogenic drugs.

Acknowledgement The authors wish to give thanks to Dr Szymon Kielbasa from Department of Computational Biology, Max Planck Institute for Molecular Genetics in Berlin, Germany for supervising the data interpretation and results.
Open Access This article is distributed under the terms of the Creative Commons Attribution Noncommercial License which permits any noncommercial use, distribution, and reproduction in any medium, provided the original author(s) and source are credited.

\section{References}

1. Baeriswyl V, Christofori G (2009) The angiogenic switch in carcinogenesis. Semin Cancer Biol 19(5):329-337

2. Fujita Y, Abe R, Shimizu H (2008) Clinical approaches toward tumor angiogenesis: past, present and future. Curr Pharm Des 14 (36):3820-3834

3. Poon RT, Fan ST, Wong J (2001) Clinical implications of circulating angiogenic factors in cancer patients. J Clin Oncol 19 (4):1207-1225

4. Uzzan B, Nicolas P, Cucherat M, Perret GY (2004) Microvessel density as a prognostic factor in women with breast cancer: a systematic review of the literature and meta-analysis. Cancer Res 64(9):2941-2945

5. Ozalp S, Yalcin OT, Acikalin M, Tanir HM, Oner U, Akkoyunlu A (2003) Microvessel density (MVD) as a prognosticator in endometrial carcinoma. Eur J Gynaecol Oncol 24(3-4):305-308

6. Bono AV, Celato N, Cova V, Salvadore M, Chinetti S, Novario R (2002) Microvessel density in prostate carcinoma. Prostate Cancer Prostatic Dis 5(2):123-127

7. Liang JT, Huang KC, Jeng YM, Lee PH, Lai HS, Hsu HC (2004) Microvessel density, cyclo-oxygenase 2 expression, K-ras mutation and p53 overexpression in colonic cancer. Br J Surg 91(3):355-361

8. Szarvas T, Jäger T, Droste F, Becker M, Kovalszky I, Romics I, Ergün S, Rübben H (2009) Serum levels of angiogenic factors and their prognostic relevance in bladder cancer. Pathol Oncol Res 15 (2):193-201

9. Tas F, Duranyildiz D, Oguz H, Camlica H, Yasasever V, Topuz E (2006) Circulating serum levels of angiogenic factors and vascular endothelial growth factor receptors 1 and 2 in melanoma patients. Melanoma Res 16(5):405-411

10. Balacescu O, Neagoe I, Balacescu L, Crisan N, Feciche B, Tudoran O, Coman I, Irimie A (2008) Angiogenesis serum protein quantification for prostate. Pathology Curr Urol 2:181-187

11. Balsari A, Maier JA, Colnaghi MI, Ménard S (1999) Correlation between tumor vascularity, vascular endothelial growth factor production by tumor cells, serum vascular endothelial growth factor levels, and serum angiogenic activity in patients with breast carcinoma. Lab Invest 79(7):897-902

12. Zhao J, Yan F, Ju H, Tang J, Qin J (2004) Correlation between serum vascular endothelial growth factor and endostatin levels in patients with breast cancer. Cancer Lett 204(1):87-95

13. Duranyildiz D, Camlica H, Soydinc HO, Derin D, Yasasever V (2009) Serum levels of angiogenic factors in early breast cancer remain close to normal. Breast 18(1):26-29

14. Weidner N, Semple JP, Welch ER, Folkman J (1991) Tumor angiogenesis et metastasis-correlation in invasive breast carcinoma. N Engl J Med 324:1-8

15. Vermeulen PB, Gasparini G, Fox SB (1996) Quantification of angiogenesis in solid human tumors: an International Consensus on the methodology and criteria of evaluation. Eur J Cancer 32:2474-2484

16. Kranz A, Mattfeldt T, Waltenberger J (1999) Molecular mediators of tumor angiogenesis: enhanced expression and activation of vascular endothelial growth factor receptor KDR in primary breast cancer. Int J Cancer 84(3):293-298

17. Ghosh S, Sullivan CA, Zerkowski MP, Molinaro AM, Rimm DL, Camp RL, Chung GG (2008) High levels of vascular endothelial growth factor and its receptors (VEGFR-1, VEGFR-2, neuropilin-1) 
are associated with worse outcome in breast cancer. Hum Pathol 39(12):1835-1843

18. Kawai H, Li H, Chun P, Avraham S, Avraham HK (2002) Direct interaction between BRCA1 and the estrogen receptor regulates vascular endothelial growth factor (VEGF) transcription and secretion in breast cancer cells. Oncogene 21(50):7730-7739

19. Ali SH, O’Donnell AL, Balu D, Pohl MB, Seyler MJ, Mohamed S, Mousa S, Dandona P (2000) Estrogen receptor-alpha in the inhibition of cancer growth and angiogenesis. Cancer Res 60 (24):7094-7098

20. Bos R, van Diest PJ, de Jong JS, van der Groep P, van der Valk P, van der Wall E (2005) Hypoxia-inducible factor-1 alpha is associated with angiogenesis, and expression of bFGF, PDGF-BB, and EGFR in invasive breast cancer. Histopathology 46(1):31-36

21. Guo P, Hu B, Gu W, Xu L, Wang D, Huang HJ, Cavenee WK, Cheng SY (2003) Platelet-derived growth factor-B enhances glioma angiogenesis by stimulating vascular endothelial growth factor expression in tumor endothelia and by promoting pericyte recruitment. Am J Pathol 162(4):1083-1093

22. Zhu L, Loo WT, Cheng CW, Chow LW (2006) Possible predictive markers related to micro-metastasis in breast cancer patients. Oncol Rep 15(5):1217-1223

23. Schweigerer L, Neufeld G, Friedman J, Abraham JA, Fiddes JC, Gospodarowicz D (1987) Capillary endothelial cells express basic fibroblast growth factor, a mitogen that promotes their own growth. Nature 325(6101):257-259

24. Gravdal K, Halvorsen OJ, Haukaas SA, Akslen LA (2006) Expression of bFGF/FGFR-1 and vascular proliferation related to clinicopathologic features and tumor progress in localized prostate cancer. Virchows Arch 448(1):68-74

25. Shi YH, Bingle L, Gong LH, Wang YX, Corke KP, Fang WG (2007) Basic FGF augments hypoxia induced HIF-1-alpha expression and VEGF release in T47D breast cancer cells. Pathology 39(4):396-400

26. Sartippour MR, Zhang L, Lu M, Wang HJ, Brooks MN (2005) Nipple fluid basic fibroblast growth factor in patients with breast cancer. Cancer Epidemiol Biomarkers Prev 14(12):2995-2998

27. Würtz SO, Schrohl AS, Mouridsen H, Brünner N (2008) TIMP-1 as a tumor marker in breast cancer-an update. Acta Oncol 47 (4):580-590
28. Hayakawa T, Yamashita K, Tanzawa K, Uchijima E, Iwata K (1992) Growth-promoting activity of tissue inhibitor of metalloproteinases-1 (TIMP-1) for a wide range of cells. A possible new growth factor in serum. FEBS Lett 298(1):29-32

29. Liu XW, Bernardo MM, Fridman R, Kim HR (2003) Tissue inhibitor of metalloproteinase-1 protects human breast epithelial cells against intrinsic apoptotic cell death via the focal adhesion kinase/phosphatidylinositol 3-kinase and MAPK signaling pathway. J Biol Chem 278(41):40364-40372

30. Liu H, Chen B, Lilly B (2008) Fibroblasts potentiate blood vessel formation partially through secreted factor TIMP-1. Angiogenesis 11(3):223-234

31. O'Hanlon DM, Fitzsimons H, Lynch J, Tormey S, Malone C, Given HF (2002) Soluble adhesion molecules (E-selectin, ICAM-1 and VCAM-1) in breast carcinoma. Eur J Cancer 38:2252-2257

32. Kostler WJ, Tomek S, Brodowicz T et al (2001) Soluble ICAM-1 in breast cancer: clinical significance and biological implications. Cancer Immunol Immunother 50:483-490

33. Kawai Y, Kaidoh M, Yokoyama Y, Sano K, Ohhashi T (2009) Chemokine CCL2 facilitates ICAM-1-mediated interactions of cancer cells and lymphatic endothelial cells in sentinel lymph nodes. Cancer Sci 100(3):419-428

34. Tsutsui S, Inoue H, Yasuda K, Suzuki K, Takeuchi H, Nishizaki T, Higashi H, Era S, Mori M (2006) Angiopoietin 2 expression in invasive ductal carcinoma of the breast: its relationship to the VEGF expression and microvessel density. Breast Cancer Res Treat 98(3):261-266

35. Helfrich I, Edler L, Sucker A, Thomas M, Christian S, Schadendorf D, Augustin HG (2009) Angiopoietin-2 levels are associated with disease progression in metastatic malignant melanoma. Clin Cancer Res 15(4):1384-1392

36. Zhou YZ, Fang XQ, Li H, Diao YT, Yang YF, Zhao DL, Wu K, Li HQ (2007) Role of serum angiopoietin-2 level in screening for esophageal squamous cell cancer and its precursors. Chin Med J (Engl) 120(14):1216-1219

37. A Randomized Phase III Trial of Paclitaxel With or Without Bevacizumab as First-Line Therapy for Locally Recurrent or Metastatic Breast Cancer: Eastern Cooperative Oncology Group trial E 2100. Abstract 7 